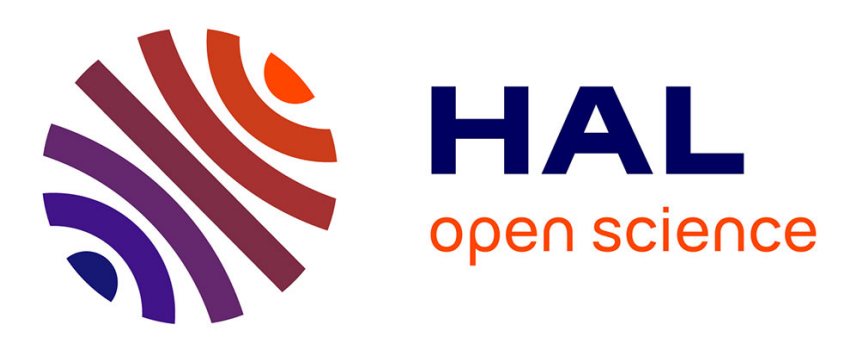

\title{
Wet lipid extraction from the microalga Nannochloropsis sp.: Disruption, physiological effects and solvent screening
}

\author{
Emilie Angles, Pascal Jaouen, Jeremy Pruvost, Luc Marchal
}

\section{To cite this version:}

Emilie Angles, Pascal Jaouen, Jeremy Pruvost, Luc Marchal. Wet lipid extraction from the microalga Nannochloropsis sp.: Disruption, physiological effects and solvent screening. Algal Research - Biomass, Biofuels and Bioproducts, 2017, 21, pp.27 - 34. 10.1016/j.algal.2016.11.005 . hal-01527160

\author{
HAL Id: hal-01527160 \\ https://hal.science/hal-01527160
}

Submitted on 21 Apr 2020

HAL is a multi-disciplinary open access archive for the deposit and dissemination of scientific research documents, whether they are published or not. The documents may come from teaching and research institutions in France or abroad, or from public or private research centers.
L'archive ouverte pluridisciplinaire HAL, est destinée au dépôt et à la diffusion de documents scientifiques de niveau recherche, publiés ou non, émanant des établissements d'enseignement et de recherche français ou étrangers, des laboratoires publics ou privés. 


\title{
Wet lipid extraction from the microalga Nannochloropsis sp.: Disruption, physiological effects and solvent screening
}

\author{
Emilie Angles, Pascal Jaouen, Jérémy Pruvost, Luc Marchal* \\ Laboratoire GEPEA, UMR CNRS 6144, University of Nantes, CRTT 37 bd de l'Université, 44602 Saint Nazaire Cedex, France
}

\begin{abstract}
A B S T R A C T
For biodiesel applications, microalgae and especially Nannochloropsis sp. are considered as a promising feedstock for lipid production. Main issues are high lipid productivity, but also robust and energy efficient downstream processes. In the biorefinery process, cellular mechanical pretreatment and solvent extraction are investigated nowadays to allow wet route lipid recovery. In this study, a method to screen solvents according their performance to extract lipids in wet condition was proposed. It consisted in short liquid/liquid extraction on cells suspension of microalgae partially disrupted. In one test, it allowed identifying for each solvent: (i) the ability to solubilize lipids compounds; (ii) the limitation by the cell wall/membrane and (iii) kinetics. The cell disruption appeared to be the main controlling step if low water soluble solvents were used. Extraction of lipids from suspension of disrupted microalgae was more efficient than extraction from dried biomass (same solvent, same energy and time) and the water presence enhanced the selectivity for saturated fatty acids recovery. $50 \%$ extraction yield was achieved with $84 \%$ disruption rate in $10 \mathrm{~min}$ and saturated fatty acids (SFA) content was enriched to $72 \%$ of the extracted lipids. The 11 solvents screening showed a significant impact of the solvent choice on a 10 min batch extraction yield. Based on the criteria considered in this study, the best solvents were Methyl tert-butyl ether (MTBE) and cyclopentylmethyl ether (CPME). They were those with Hansen solubility parameters close to the target fatty acids, low solubility in water and low heat of vaporization. They represent alternatives to chlorinated solvents or alkanes.
\end{abstract}

\section{Introduction}

Microalgae appeared in the last decades as a promising alternative feedstock for biodiesel production [1-3]. By strain screening, metabolomics, processing conditions and photobioreactors intensification the lipid accumulation as oleosomes inside the cells has been significantly enhanced [4-6]. For biodiesel applications, the lipid fraction of major interest is triacylglycerides of saturated fatty acids. Main issues are obviously high lipid productivity at the photobioreactor step, but robust and energy efficient downstream processes are also necessary. For example the energy balance in the case of dry route lipid extraction is not positive. According to K. Sander and G. Murthy [7], the minimum net energy input is $-3982 \mathrm{MJ}$ for $24 \mathrm{~kg}$ of biomass with a lipid content between 30 and $40 \%(w / w)$, necessary for the production of $1000 \mathrm{MJ}$ algae biodiesel. In the dry route, the microalgae biomass is first dewatered by filter press or centrifugation to obtain $80-90 \%$ moisture and then by a natural gas dryer to finish at less than $10 \%$ moisture. However, a natural gas dryer requires $3556 \mathrm{~kJ} / \mathrm{kg}$ water removed which represents $89 \%$ of the total energy input. Generally life-cycle assessment

\footnotetext{
* Corresponding author.

E-mail address: luc.marchal@univ-nantes.fr (L. Marchal).
}

(LCA) studies of biodiesel from microalgae pointed out that the step which requires the most energy input is the biomass drying operation. If the energy input is reduced with an improvement or removal of drying operation, the net energy balance would be positive [7-9]. Consequently the lipid recovery by wet extraction is of particular interest to reduce the energy demand [10-12]. As well, the biorefinery concepts try to valorize the whole biomass as a strategy to decrease the overall cost of the production. It must not exceed $0.25 \$ / \mathrm{kg}$ to compete the petroleum, according Y. Chisti [13].

Wet solvent extraction of lipids is a unit operation based on a mass exchange between an aqueous feed and an organic solvent phase. As recently described [14-15], biphasic extraction needs a preliminary cell disruption for solvent accessibility to the lipids. Cell rupture can be obtained by chemical or enzymatic treatments, by electrical treatments especially for hydrophilic molecules release [16] or by mechanical treatments (French press, high pressure homogenizer, bead milling [17-21]). Mechanical disruption has the advantage to be continuous, with no matter addition (acids, enzymes, solvents...) that simplify downstream processing and scalability to industrial level. Another point is the possibility to treat the biomass with variable dry matter concentrations corresponding to the concentration obtained at the harvesting step outlet (around $10-30 \% \mathrm{dw}$ ) or the concentration considered for 
the extraction step $(0.1-1 \% \mathrm{dw})$. It must be denoted that energy consumption for mechanical processing is important and correlated to the volume to treat - the biomass concentration has then to be as concentrated as possible [15]. Main limitation is then the tremendous increase of the suspension viscosity with the dry matter content of the culture, starting from fluid suspension like water to a compact paste. For high pressure processes, matter needs to be fluid for efficient disruption, limiting the biomass concentration at $1 \% \mathrm{dw}$. Otherwise for bead milling, the limitation is only the pumpability of the product to feed the unit, pushing the limit to $5-15 \%$ dw but the efficiency at these concentrations has not been clearly described for the moment. Mechanical processes seem to be especially convenient for lipophilic fraction release without altering the biochemical integrity of the other fractions (proteins, pigments, polysaccharides). In this study, high pressure disruption will be considered at lab-scale as it is efficient and especially convenient for the treatment of small volumes of culture ( $10 \mathrm{~mL}$ of culture at $1 \mathrm{~g} / \mathrm{L})$.

Microalgae have very different size, topology, composition and thus mechanical robustness. Strain and physiological impact on robustness might be important parameters that should be studied and taken into account for process development [20,22-23].

The solvent choice is also a critical step for extraction process development, but in fact few data are available in this field on solvent screening, including green solvents, and their rationalized comparison. Solvent choice for extraction requires almost 12-15 criteria that must be compared and integrated for technical and economical optimization. These criteria can be organized in 3 groups: "extraction capability", "solvent recycling" and "health and safety". For liquid-liquid extraction, the solvent has to be poorly soluble in water. A solvent of interest allows an efficient and rapid recovery of the lipid fraction. The best solvent should be easy to recycle (mainly by vaporization; low boiling temperature and low heat of vaporization) and with minimum risk for human and environment (chlorinated solvents are not candidates for large scale use for example). Most encountered solvents in the literature are alkanes (hexane and heptane), alcohols (methanol, ethanol, propanol), chlorinated (dichloromethane and chloroform) [24-25] and some alternative solvents like supercritical $\mathrm{CO}_{2}$ [26-27], ionic liquids [28-29] or some terpenes [30-33]. Chloroform $\left(\mathrm{CHCl}_{3}\right)$ is the most encountered in lipid extraction standard analytical methods. Alkanes like hexane are usual in plant oil industry. Heptane and the cyclohexane, as aliphatic and cyclic hydrocarbons, have a higher number of carbons than hexane and then a lower volatility and toxicity. Others conventional solvents are toluene as aromatic hydrocarbon, methyl isobutyl ketone (MIBK) [34] from ketone class and ethyl acetate (EtOAc), as an ester. Toluene and MIBK are mostly used in paints and lacquers industry. EtOAc is a green solvent with reduced human impact, considered as a substitute to chlorinated solvents in industry [31]. Unconventional solvents from green chemistry can also be referenced: dimethyl carbonate (DMC) $[25,35]$ is produced from renewable resources as well as cyclopentylmethyl ether (CPME), methyl tert butyl ether (MTBE) [34, 36-37] and the 2-methyl tetrahydofuran (MeTHF). R-limonene [3133] completes the list as a terpene from essential oil.

This article proposes a methodological development for pretreatment and solvent choice, applied to wet (diluted) extraction of lipids from microalgal biomass. Extraction process evaluation is based on the solvent price, availability, distillation cost that depend on the solvent nature, but also on the solvent extracting power (extraction efficiency) and the extraction technology (mixer-settler, columns, centrifuge). This experimental work focused on the solvent lipids extracting efficiency criteria, in the case of diluted biomass.

Nannochloropsis sp. was used a microalga model for lipid production, mechanical robustness and variability with physiological state. The method development started with a microalgal mechanical disruption study as a pretreatment. The high pressure cell disruption was chosen as an easily tunable and efficient technique to modulate the cellular integrity at laboratory scale. Then, the effect of the water presence on the extraction yield and selectivity was considered for two different solvents chloroform:methanol (2:1) and heptane. At last, 11 solvents were tested on a short duration lipid extraction, with the same energy input and solvent-to-feed ratio $(\mathrm{S} / \mathrm{F})$ of 0.5 . The solvents were chosen within various chemical classes to test their extracting efficiency. They were compared according to the Hansen solubility parameters, the total fatty acid (TFA) extraction yield, their solubility in water and the required energy for recycling by vaporization, to propose an objective test before process development. Necessary solvent quantity minimization and biomass concentration increase will be discussed considering large-scale application.

\section{Material and methods}

\subsection{Biomass}

Nannochloropsis sp. strain was obtained from Alphabiotech collection (Asserac, France). Microalgae were cultivated in a modified Conway medium (3N3P) using artificial seawater at $25 \mathrm{~g} \cdot \mathrm{L}^{-1}$ of salt (ASW) [6,38-39]. The medium was filtered at $0.2 \mu \mathrm{m}$ to remove any microbial contamination (Sartolab P20, Sartorius SAS, Germany). The biomass production was performed in $1 \mathrm{~L}$ airlift-type flat panel photobioreactor (PBR) [5]. The $\mathrm{pH}$ was regulated at 8 by $\mathrm{CO}_{2}$ injection and the temperature at $22^{\circ} \mathrm{C}$ was monitored by a pH sensor (Mettler Toledo SG 3253). Two different physiological states were obtained. The first one was obtained for a continuous biomass production with replete nitrogen (N-replete) with a continuous exposition to $150 \mu \mathrm{mol}_{\mathrm{hv}} \cdot \mathrm{m}^{-2} \cdot \mathrm{s}^{-1}$ of white light. The second one was obtained for a batch reactor under progressive nitrogen starvation ( $\mathrm{N}$-starved) and higher photons flux to $220 \mu \mathrm{mol} \cdot \mathrm{m}^{-2} \cdot \mathrm{s}^{-1}$ inducing lipid and especially triacylglycerides (TAG) accumulation [6,38]. The nitrogen concentration was followed by ion-exchange chromatography; biomass and TFA content were followed every day by dry matter and GC-FID. Maximum TFA content was obtained 96-120 h after fully N-depleted conditions. Each batch was harvested from the PBR to a sterile glass bottle and directly used for further studies.

\subsection{High pressure disruption}

Disruption of biomass was performed using a high pressure disrupter Cell-D 2.2 kW (series B, Constant systems Ltd., Warwick, (UK)). Samples were treated by $10 \mathrm{~mL}$ shots at pressures ranging from 100 to $270 \mathrm{MPa}$ [23]. The energy consumption of the cell disrupter is scaled linearly with the pressure as calculated with Eq. (1)

$\mathrm{P}_{\mathrm{H}}=\mathrm{F}_{\mathrm{X}} \cdot \Delta \mathrm{P} \cdot \eta_{\mathrm{c}}$

The hydraulic power $\left(\mathrm{P}_{\mathrm{H}}\right)$ depends on the flow rate $\left(\mathrm{F}_{\mathrm{x}}\right)$, the pressure applied $(\triangle \mathrm{P})$ and the rate of the energy delivered on the input energy $\left(\eta_{c}\right)$. Cell disruption rate \% $\tau$ d (cells) can be calculated with Eq. (2)

$\% \tau d($ cells $)=\frac{[\mathrm{X}]_{0}-[\mathrm{X}]_{\mathrm{f}}}{[\mathrm{X}]_{0}} \times 100$

With $[\mathrm{X}]_{0}$ the initial cell concentration and $[\mathrm{X}]_{\mathrm{f}}$ the cell concentration after treatment.

Cell concentration was determined under microscope using a Malassez cell. Samples from the initial batch of algal suspension has an average cell concentration of $10^{8}$ cells $\cdot \mathrm{mL}^{-1}$ and after disruption was diluted with an appropriate factor (DF) to obtain a cell concentration between 30 and 100 per mesh. $10 \mu \mathrm{L}$ of Iodine-Potassium iodide (IKI) solution was added to $1 \mathrm{~mL}$ to help cells decantation before counting. Numbering was performed on 10 meshes per sample. 


\subsection{Analytical methods}

Standard lipid extraction before analysis used "whole cell analysis" (WCA) method [38]. $2 \mathrm{~mL}$ of microalgae cultures was sampled in Pyrex glass vials and centrifuged $10 \mathrm{~min}$ at $3600 \mathrm{~g}$ and $10{ }^{\circ} \mathrm{C}$ (Mikro $22 \mathrm{R}$, Hettich, UK). Supernatant was removed and microalgae were frozen at $-80{ }^{\circ} \mathrm{C}$ prior to freeze-drying. The powder was re-suspended in $6 \mathrm{~mL}$ of a $\mathrm{CHCl}_{3}: \mathrm{MeOH}$ mixture $(2: 1, \mathrm{v}: \mathrm{v})$. Vials were maintained $6 \mathrm{~h}$ in the dark at $20 \pm 2{ }^{\circ} \mathrm{C}$ and under slow agitation on a tube roller.

After wet extraction, organic and aqueous phases were separated and the solvent of the extracts was evaporated under $\mathrm{N}_{2}$ flux after adding $0.01 \% \mathrm{w} / \mathrm{w}$ of butylated hydroxytoluene (BHT) as antioxidant. $1 \mathrm{~mL}$ of $\mathrm{CHCl}_{3}: \mathrm{MeOH}$ mixture $(2: 1, \mathrm{v} / \mathrm{v})$ was then added and stored at $-20^{\circ} \mathrm{C}$ until analysis.

Total fatty acids content in the lipid extracts were quantified by Gas Chromatography-Flame Ionization Detector (GC-FID) analysis after a transesterification step to obtain fatty acid methyl ester (FAME). More details can be found in [38].

Pigments content of biomass culture were determined using a spectrophotometric method. $1.5 \mathrm{~mL}$ of biomass culture was centrifuged at $12,000 \mathrm{~g}$ for $10 \mathrm{~min}$. Supernatant was removed and the pellet was suspended in $1.5 \mathrm{~mL}$ of pure $\mathrm{MeOH}$ in a sonication bath during $10 \mathrm{~s}$. Pigments were extracted during $1 \mathrm{~h}$ at $45^{\circ} \mathrm{C}$. After wet extraction, organic and aqueous phases were separated and the solvent of the extracts was evaporated under $\mathrm{N}_{2}$ flux. Pigments in the extract were recovered by adding $1.3 \mathrm{~mL}$ of methanol and $0.2 \mathrm{~mL}$ of heptane. Aliquots were centrifuged. Absorbance (A) of supernatants was measured at 750, 665 and $480 \mathrm{~nm}$ using a double beam spectrophotometer (V-630, Jasco, Japan). A dilution factor (DF) was applied for highly concentrated phases to ensure absorbance below $1 \mathrm{AU}$. Chlorophyll a concentration $\left(\mathrm{C}_{\mathrm{Chl} a}\right)$ and carotenoid concentration $\left(\mathrm{C}_{\mathrm{cart}}\right)$ were estimated according to the correlation of Talling and Driver (Eq. (3) and Strickland and Parsons (Eq. (4) [26].

$\mathrm{C}_{\text {Chl } a}(\mu \mathrm{g} / \mathrm{mL})=13,9 \times\left(\mathrm{A}_{665}-\mathrm{A}_{750}\right) \times \mathrm{DF}$

$\mathrm{C}_{\text {cart }}(\mu \mathrm{g} / \mathrm{mL})=4 \times\left(\mathrm{A}_{480}-\mathrm{A}_{750}\right) \times \mathrm{DF}$

Each lipids and pigments analysis was done in triplicates with a standard deviation of $5 \%$ and $6 \%$ respectively. Glassware used was heated $6 \mathrm{~h}$ at $450{ }^{\circ} \mathrm{C}$ to prevent from any organic pollution.

\subsection{Solvents}

Eleven solvents were chosen among hydrophobic solvents from various chemical families in the purpose to have a whole range representation of solvent used in extraction field with their different physical properties. There were one halogenated solvent (chloroform $\mathrm{CHCl}_{3}$ ), two alkanes (heptane and cyclohexane), one aromatic hydrocarbon (toluene), one ketone (methyl isobutyl ketone MIBK), two esters (ethyl acetate EtOAc and dimethyl carbonate DMC), one terpene (Rlimonene) and three ethers (cyclopentyl methyl ether CPME, methyl tert-butyl ether MTBE and the 2-methyl tetrahydrofuran MeTHF). Among this selection it was taken in account to have usual solvents and others issued from the green chemistry considered as alternatives solvents such as last enumerated from EtOAc to MeTHF. All solvents were obtained from Sigma-Aldrich with analytical grade except heptane purchased from VWR in technical grade. Solvents characteristics are summarized in Table 1. Hansen's solubility parameters (HSP) were obtained from [40]. Molecular cohesion energy for each molecule (E) can be decomposed into three main interactions, dispersive London's interaction (Ed), polar Keesom's interaction (Ep) and Hydrogen's bonding (Eh). Three solubility parameters can be calculated $\delta \mathrm{d}, \delta \mathrm{p}, \delta_{\mathrm{H}}$, like Hildebrand' solubility parameters ( $\delta$ ), as the square root of cohesion energy (E) divided by the molar volume $\left(\mathrm{V}_{\mathrm{M}}\right)[14,31,40]$. Two of these parameters $\left(\delta p\right.$ and $\delta_{\mathrm{H}}$ ) are sufficient to build a 2D Hansen map as $\delta \mathrm{d}$, is not very sensitive for solvents [31].

\subsection{Extraction}

Wet and dry extractions were performed in Pyrex glass test tubes of $15 \mathrm{~mL}$ in triplicate. Wet extraction used $10.0 \pm 0.2 \mathrm{~mL}$ of cultures at $1.34 \mathrm{~g} \cdot \mathrm{L}^{-1}$ of $\mathrm{N}$-starved biomass with $5.0 \pm 0.2 \mathrm{~mL}$ of solvent to obtain a volume ratio of solvent per aqueous phase $(\mathrm{S} / \mathrm{F})$ of 0.5 . Dry extraction used the same biomass quantity but in freeze dried powder. The volume of solvent used was on dry matter $(\mathrm{dw})$ basis, i.e. $3.73 \mathrm{~mL} \cdot \mathrm{g}^{-1} \mathrm{dw}$. In both cases, extraction was performed during $10.00 \pm 0.02$ min with mixing at $2500 \mathrm{rpm}$ (vortex, VWR) at $20 \pm 0.4^{\circ} \mathrm{C}$. Samples were centrifuged $10.00 \pm 0.02 \mathrm{~min}$ at $3600 \mathrm{~g}$-force and $20.0 \pm 0.4{ }^{\circ} \mathrm{C}$ (Mikro 22R, Hettich, UK). The organic phase was aliquoted in Pyrex vials for lipids and pigments quantification. The extraction yield of total fatty acids (TFA) and pigments were calculated as the following equation:

$\eta_{\mathrm{E}, \mathrm{Tn}}=\frac{\mathrm{m}_{\mathrm{E}, \mathrm{Tn}}}{\mathrm{m}_{\mathrm{Tn}, 0}} \times 100$

With $\mathrm{n}$ lipids compounds, such as pigments with carotenoids (cart) or chlorophyll $a\left(\mathrm{Chl} a\right.$ ) or fatty acids (FA), $\mathrm{m}_{\mathrm{E}, \mathrm{Tn}}$ : mass of the extracted compound, $\mathrm{m}_{\mathrm{Tn}, 0}$ : initial mass of the considered compound.

The ratio of each FA considered on the TFA was determined as:

$$
\frac{\mathrm{FA}}{\mathrm{TFA}_{, \mathrm{E}}}=\frac{\mathrm{m}_{\mathrm{FA}, \mathrm{i}}}{\mathrm{m}_{\mathrm{E}, \mathrm{TFA}}} \times 100
$$

Table 1

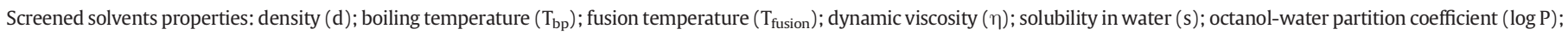

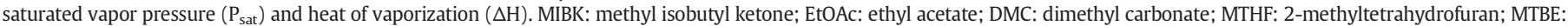
methyl ter-butyl ether; CPME: cyclo pentyl methyl ether.

\begin{tabular}{|c|c|c|c|c|c|c|c|c|c|c|c|}
\hline Solvent & Cyclohexane & Heptane & Chloroform & Toluene & MIBK & EtOAc & DMC & R-Limonene & MeTHF & MTBE & CPME \\
\hline Molecular formula & $\mathrm{C}_{6} \mathrm{H}_{12}$ & $\mathrm{C}_{7} \mathrm{H}_{16}$ & $\mathrm{CHCl}_{3}$ & $\mathrm{C}_{7} \mathrm{H}_{8}$ & $\mathrm{C}_{6} \mathrm{H}_{12} \mathrm{O}$ & $\mathrm{C}_{4} \mathrm{H}_{8} \mathrm{O}_{2}$ & $\mathrm{C}_{3} \mathrm{H}_{6} \mathrm{O}_{3}$ & $\mathrm{C}_{10} \mathrm{H}_{16}$ & $\mathrm{C}_{5} \mathrm{H}_{10} \mathrm{O}$ & $\mathrm{C}_{5} \mathrm{H}_{12} \mathrm{O}$ & $\mathrm{C}_{6} \mathrm{H}_{12} \mathrm{O}$ \\
\hline $\mathrm{d}\left(\mathrm{g} / \mathrm{cm}^{-3}\right)$ & 0.78 & 0.68 & $1.48^{\mathrm{b}}$ & 0.87 & $0.80^{\mathrm{b}}$ & $0.90^{\mathrm{a}}$ & $1.07^{\mathrm{b}}$ & $0.84^{\mathrm{b}}$ & $0.86^{\mathrm{a}}$ & $0.74^{\mathrm{b}}$ & 0.86 \\
\hline $\mathrm{T}_{\mathrm{bp}}\left({ }^{\circ} \mathrm{C}\right)$ & 81 & 98 & 61 & 111 & 117 & 77.1 & 90 & 176 & 80 & 55 & $106^{\mathrm{b}}$ \\
\hline $\mathrm{T}_{\text {fusion }}\left({ }^{\circ} \mathrm{C}\right)$ & 4.0 to 7.0 & -91 & -63 & -95 & -80 & -83.60 & 2.0 to 4.0 & -75 & -136 & -109 & -140 \\
\hline$\eta(\mathrm{mPa} \cdot \mathrm{s})$ & 0.98 & 0.39 & $0.57^{\mathrm{a}}$ & 0.59 & 0.58 & $0.42^{\mathrm{b}}$ & 0.59 & $0.83^{\mathrm{b}}$ & $0.60^{\mathrm{b}}$ & 0.47 & 0.55 \\
\hline$s(g / L)$ & Insoluble & 0.05 & 8.22 & 0.53 & 20 & 83 & $139^{a}$ & Insoluble & $140^{\mathrm{a}}$ & $26^{\mathrm{a}}$ & 11 \\
\hline Log P & 3.44 & $>3.00$ & 1.97 & 2.46 & 1.31 & 10 & $0.23^{\mathrm{b}}$ & 2.67 & 1.26 & 1.3 & $1.59^{\mathrm{a}}$ \\
\hline $\mathrm{P}_{\text {Sat }}(\mathrm{kPa})$ & 10.4 & 4.7 & 21.3 & 2.9 & 2.0 & 9.3 to 11.3 & $2.4^{\mathrm{c}}$ & 0.4 & 10.0 & $27.0^{\mathrm{b}}$ & 6.0 \\
\hline$\Delta \mathrm{H}(\mathrm{kJ} / \mathrm{kg})$ & 390 & 373 & 262 & 426 & 488 & 394 & 516 & 323 & 375 & 337 & 289 \\
\hline Class & Alkane & Alkane & Halogenated & Aromatic & Ketone & Ester & Ester & Terpene & Ether & Ether & Ether \\
\hline
\end{tabular}

\footnotetext{
a At $20^{\circ} \mathrm{C}$.

b At $25^{\circ} \mathrm{C}$.
}

c At $21.1^{\circ} \mathrm{C}$. 


\section{Results and discussion}

\subsection{Biomass characteristics}

Two Nannochloropsis sp. culture were studied, N-replete culture and $\mathrm{N}$-starved culture at $1.1 \pm 0.3 \mathrm{~g} \cdot \mathrm{L}^{-1}$. N-starved culture has a total fatty acid content of $44 \%$ dw while $\mathrm{N}$-replete culture reached $11 \%$ as previously observed [41-42]. Here the $\mathrm{N}$-starved biomass lipid fraction contained $57.0 \pm 0.6 \%$ of Saturated Fatty Acids, mainly palmitic acid (C16:0, $48 \pm 0.5 \%), 38.0 . \pm 0.3 \%$ of Mono Unsaturated Fatty Acids, with palmitoleic acid and oleic acid (C16:1n-7, 28.0. \pm 0.1\%; C18:1n-9c, $10.0 \pm 0.0 \%$ ) and $5.0 \pm 0.9 \%$ of Poly Unsaturated Fatty Acids, including Ethyl Eicosapentaenoic Acid (EPA, C20:5n-3, $2.0 \pm 0.4 \%$ ) (Fig. 1A and $B)$. This result is in accordance with results in previous works on a Nannochloropsis strain cultivated under nitrogen deprivation and highlighted the overexpression of saturated fatty acids in oleosomes $[41,42]$. Moreover, the slight change proportion of polar and phospholipids observed by L. Rodolfi [41] and P. Bondioli [42] supposed no important change in structural lipid content and consequently the $57 \%$ of saturated fatty acids are mostly de novo synthesis as TAG, increasing de TFA content from $11 \%$ to $44 \%$, which are stored as lipid droplets in the cytoplasm $[33,43-46]$.

\subsection{High pressure cell-disruption}

The two Nannochloropsis sp. culture broths were treated by high pressure impacting jets from 100 up to $270 \mathrm{MPa}$. Cultivation conditions effect on the physiological state (N-replete and N-starved) and the microalgal response can then be discussed. For both conditions, the cell disruption rate increased with the operating pressure (Fig. 2). For $\mathrm{N}$-replete cultivation conditions, disruption rate varied between 20 and $58 \%$ for 100 up to $270 \mathrm{MPa}$ pressure treatments. In N-starved conditions, disruption rates were lower, between 11 and $48 \%$ for the same pressure treatments. It appeared then that when the physiology of Nannochloropsis sp. is modified by nitrogen depletion for lipid enrichment, the microalgae also reinforce their robustness. The two curves had a quite sigmoidal shape with an inflexion point at the "critical pressure". The critical pressure values were 125 MPa for N-replete cultivation conditions and $230 \mathrm{MPa}$ for the N-starved conditions ones. This microalgal species is known as highly resistant to break up [26,47]. Furthermore enhancement of lipid productivity by nitrogen depletion would have a deep impact on the down-stream processing with an energetic consumption which is twice higher at the cell disruption step.

\subsection{Lipid extractability: heptane vs $\mathrm{CHCl}_{3}-\mathrm{MeOH}$, wet vs dry route}

In this part, lipid recovery after biomass pretreatment was investigated to compare wet to dry route extraction. Even if the disruption

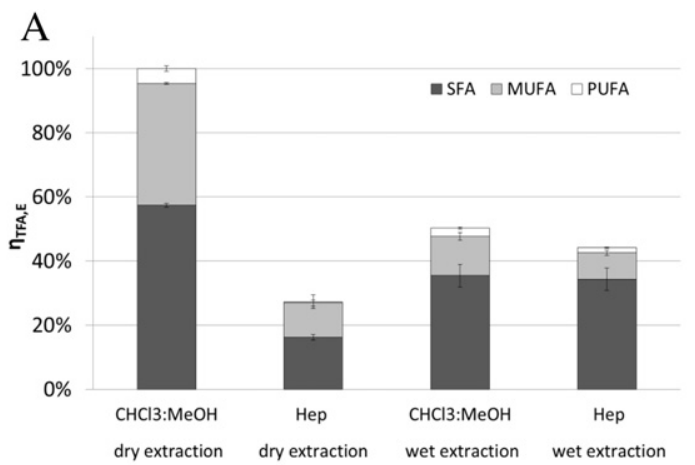

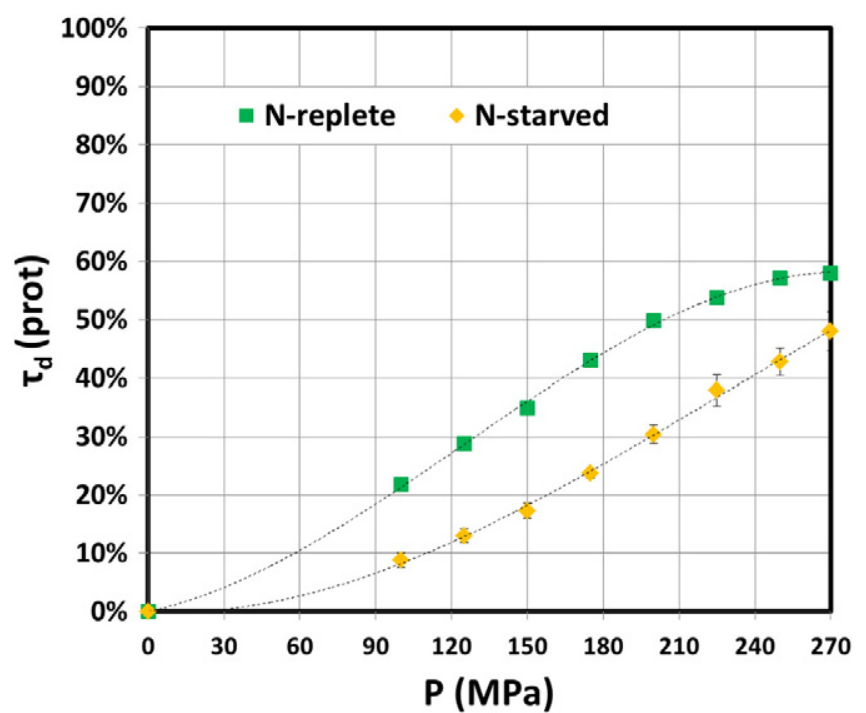

Fig. 2. Cell disruption rate of Nannochloropsis sp. cells cultivated in N-repleted or N-starved conditions as a function of the applied pressure (Continuous line: 3rd order polynomial regression) (Error \pm SD for triplicates);

was more difficult, lipid extraction study was done on the N-starved Nannochloropsis sp. which contains lipids of interest (TAG). The algal biomass contained $1.3 \mathrm{~g} \cdot \mathrm{L}^{-1}(\mathrm{dw})$ and the total fatty acids content was $44 \%$ (dw). The extractions identified as "Dry" and "Wet" were conducted in conditions described in part 2.5. On one hand, the organic and aqueous volume phase or dry weight biomass were fixed and on other hand the extraction time $(10 \mathrm{~min})$, temperature $\left(20^{\circ} \mathrm{C}\right)$ and agitation (vortex, $2500 \mathrm{rpm}$ ) were also determined to have the same energy input for each assays. The extraction duration on dry biomass (dry) was limited to $10 \mathrm{~min}$ (despite of $6 \mathrm{~h}$ for standard analysis).

$\mathrm{CHCl}_{3}$ :MeOH dry extraction yield was equivalent to the reference standard extraction. $100 \%$ of TFA was recovered in this case (Fig. 1A) with the same SFA/MUFA/PUFA distribution. In these conditions, the lipid extractability was complete and 10 min were sufficient for total recovery. For heptane dry extraction, the yield fell to $27 \pm 3 \%$ in $10 \mathrm{~min}$, showing a kinetic limitation often encountered when dry material have to be wetted and impregnated by apolar phases (Fig. 1A, Hep dry). In fact, in the same mixing conditions, it was more difficult to disperse the dried powder in heptane than in $\mathrm{CHCl}_{3}: \mathrm{MeOH}$. This kind of limitation was not observed in wet route as wettability and impregnation are not involved in this case. For these experiments, the cell disruption rate was $84 \%$ and lipids recovery with heptane and $\mathrm{CHCl}_{3}: \mathrm{MeOH}$ reached $44 \%$ and $50 \%$ respectively in $10 \mathrm{~min}$ (Fig. $1 \mathrm{~A}$ ). Water presence, as a barrier, could explain the lowering of the extraction kinetics of

\section{B}

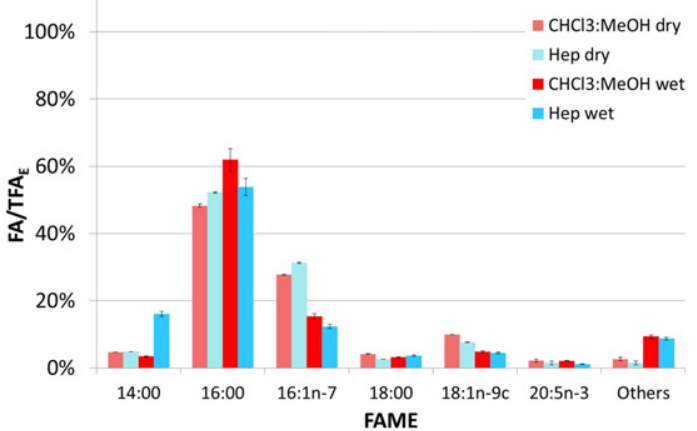

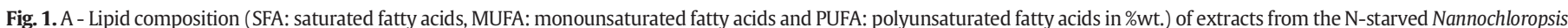

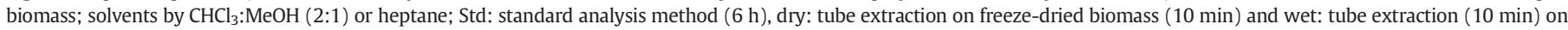

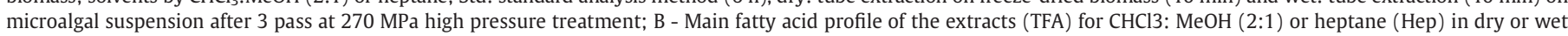
conditions. Fatty acids $<2 \%$ of TFA are grouped as "others". ((Error \pm SD for three replicates $(n=3)$ ). 


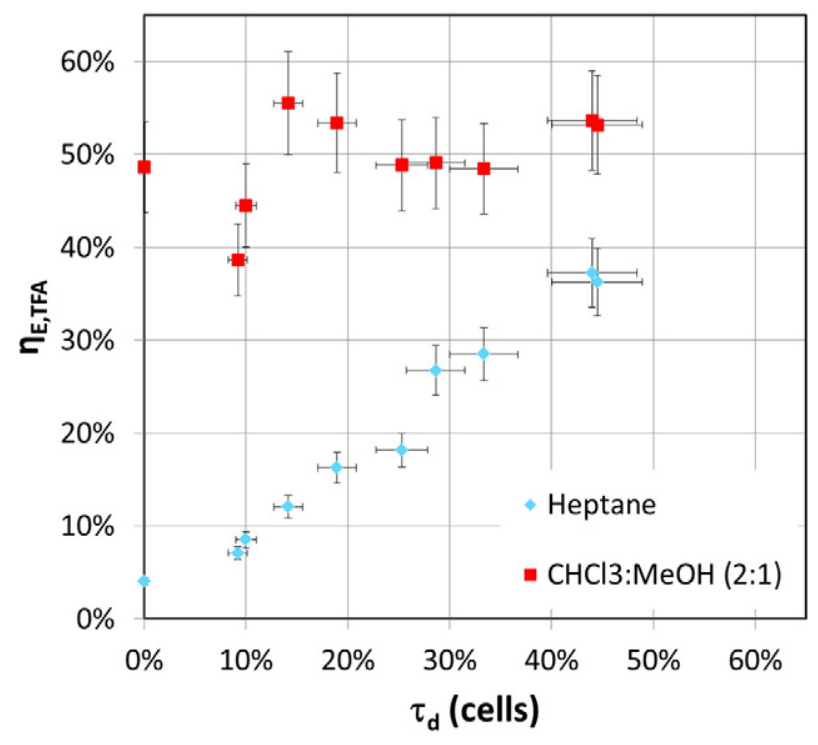

Fig. 3. $\eta_{\text {TFA }}$, TFA wet extraction yields for $\mathrm{CHCl}_{3}: \mathrm{MeOH}(2: 1)$ and heptane, for various cell disruption rates.

chloroform in wet route. For heptane, wettability and dispersion problems were not encountered anymore, and the extraction efficiency was improved. Using wet route, SFA recovery was $72 \pm 1 \%$ for both solvents, whereas unsaturated fatty acids (MUFA + PUFA) recovery was 35 and $23 \%$ for $\mathrm{CHCl}_{3}: \mathrm{MeOH}$ and heptane respectively. Unsaturated fatty acids were more difficult to extract in presence of water like for example 16:1n-7 and 18:1n-9c (Fig. 1B), making the operation more selective. The selectivity was more important with heptane than with $\mathrm{CHCl}_{3}: \mathrm{MeOH}$. Finally, on one hand water presence of wet route extraction improved lipids extraction efficiency for immiscible solvent like heptane and on other hand reduced the amount of lipids extracted by $\mathrm{CHCl}_{3}: \mathrm{MeOH}$. SFA were preferentially extracted by wet route, which should be an advantage as SFA, mainly encountered as triacylglycerides, are the targeted fraction for high biodiesel quality $[3,48]$.

\subsection{Disruption rate effect on lipid extractability}

Wet extraction performances were compared between $\mathrm{CHCl}_{3}: \mathrm{MeOH}$ and heptane as a function of the cell disruption rate $(0-44 \pm 2 \%$, corresponding to 0-270 $\mathrm{MPa}$ ) in conditions previously described in the part 2.5 (Fig.3). When $\mathrm{CHCl}_{3}: \mathrm{MeOH}$ was used, $49 \pm 5 \%$ extraction yield was achieved whatever the pretreatment intensity was. The $\mathrm{CHCl}_{3}: \mathrm{MeOH}$ mixture could have a lytic effect on microalgae; $\mathrm{MeOH}$ partitions in the water phase with high solvent toxicity for the cells [1]. Extraction yield was then only controlled by the solid-liquid-liquid mass transfer limitations. For heptane, the TFA extraction yield was proportional to the disruption rate within the experimental range. For this category of solvent (no solubility in water), the extraction was fully controlled by the intracellular release during the pretreatment process. For a $44 \pm 2 \%$ disruption rate, $37 \pm 4 \%$ of TFA were extracted.

The extracts were not colorless; they also contained pigments such as carotenoids and chlorophylls that were present in oleosomes and chloroplasts. Analyses of pigment content are presented on Fig. 4 for extraction with heptane according to the cell disruption rate. The ability of heptane to extract fatty acids, carotenoids and chlorophylls slightly differed between them. For mild pressure treatments (below $175 \mathrm{MPa}$ ), chlorophyll $a$ appeared to be significantly less extractable than carotenoids and fatty acids. At $125 \mathrm{MPa}$, at $36 \pm 1 \%$ of normalized disruption rate $\left(\tau_{\mathrm{d}, \mathrm{N}}\right), 23 \pm 1 \%$ of chlorophylls was extracted against $30 \pm 2 \%$ of carotenoids and $38 \pm 4 \%$ of fatty acids. However, for higher pressure (beyond $200 \mathrm{MPa}$ ), chlorophyll a recovery was similar to carotenoids one. At $79 \%$ of normalized disruption rate, for both pigments $66 \pm 2 \%$ was recovered and $76 \pm 7 \%$ for fatty acids. The extractability difference between these lipids was less significant in this range of pressures applied (200 MPa to $270 \mathrm{MPa}$ ). Below the critical pressure of N-starved biomass determined in part 3.1 ( $\mathrm{P}<230 \mathrm{MPa})$, where less than $50 \%$ of cells was disrupted, a slight selectivity between carotenoids and chlorophyll $a$ was obtained. In these conditions, the cell rupture mechanism could be milder leading to a partial chloroplast content release. The fine tuning and control of the cell disruption process allows notably preparing the feed before extraction, limiting the release of unwanted molecules, even getting a selective release of the organelles content $[21,26]$.

\subsection{Solvent screening}

Eleven solvents with miscellaneous chemical functional groups at low or partial solubility with water were selected (Table 1).

For each solvent, extraction in wet route was applied as described in part 2.5 with a $29 \%$ cell disruption rate. As shown in part 3.3, the disruption has an impact on the lipid recovery that can be more or less important according to the solvent. At $29 \%$ cell disruption and short time extraction (1-10 min), the purpose was to identify in one simple test for each solvent: (i) ability to extract lipids compounds; (ii) limitation by the cell wall/membrane and (iii) kinetics.

TFA extraction yields ( $\eta_{\text {TFA,E }}$ ) are presented on the Fig. 5A. Solvents behavior can be classified into 3 groups: (i) the "good solvents" which got extraction rates similar to disruption rate (EtOAc, MIBK, CPME, toluene), (ii) the "best solvents" extracting more than the released lipids in aqueous medium by cells disruption $\left(\mathrm{CHCl}_{3}, \mathrm{MTBE}, \mathrm{MeTHF}\right)$ and (iii) "less efficient" ones with slower extraction (heptane, cyclohexane, DMC, R-limonene). For all the solvents, the Hansen solubility parameters were collected and/or calculated [2]. Results are presented on a Hansen Map (Fig. 5B). Standard target molecules were also chosen, representing the lipids to be extracted: oleic acid triglyceride (C18:1n9) for the TAGs, stearic acid (C18:0) and oleic acid (C18:1) for SFA and MUFA respectively. Each molecule was plotted in the 2D-Hansen Map. The distance between two points, i.e. the Hansen Solubility Parameter difference (HSP) reflects the difficulty for 2 compounds to solubilize themselves. As a result (Fig. 5), the extraction efficiency of the tested solvents was in fact as important as the solvent dot was closed to the target molecule in the Hansen map. The phenomenon is of course much more complex than a solvation one, especially due to the water presence. Nevertheless, the use of Hansen solubility parameters gave

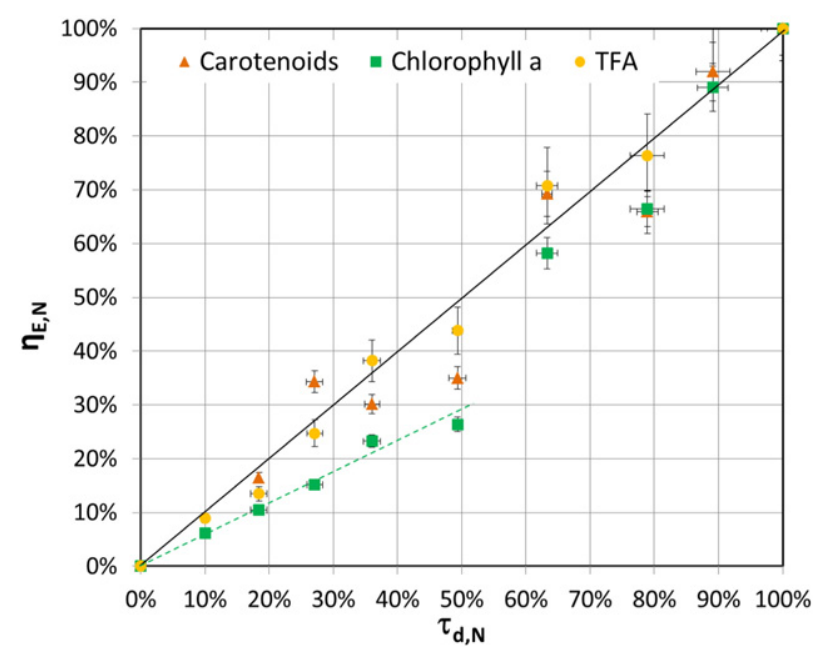

Fig. 4. $\eta_{\text {TFA N }}$, Normalized heptane wet extraction yields of TFA, Carotenoids and Chlorophyll $a$ on $\mathrm{N}$-starved Nannochloropsis sp. biomass as a function of normalized disruption rates. _Continuous line $\left(\eta_{\mathrm{E}, \mathrm{N}}=\tau_{\mathrm{d}, \mathrm{N}}\right)$ when extraction yield is directly proportional to disruption and dotted line for $\mathrm{Chl} a$ behavior at small pressure. 
A

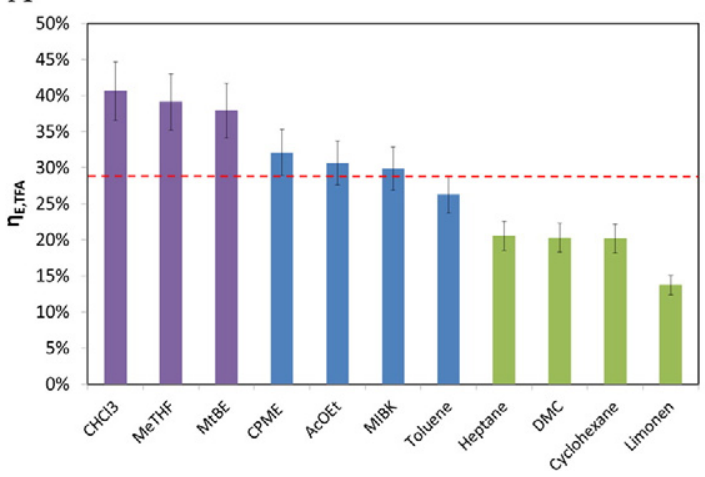

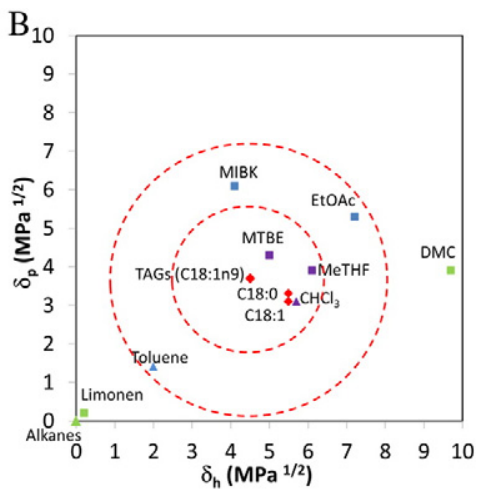

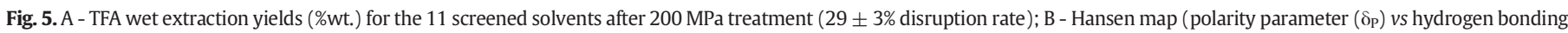

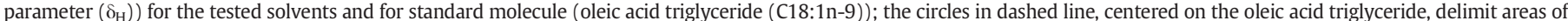
solvents from the closest to the farthest.

qualitative information for the solvents extraction efficiency (or capability). This well-known approach in the solvent extraction field (leaching for instance) seems to be craftily transposed here for solid-liquid-liquid extraction of hydrophobic compounds in colloidal aqueous suspension, considering the water as a matrix. The main difference with leaching is that solvent diffusion inside solid porous particles is replaced by an interfacial mass transfer that can be modulated by liquidliquid hydrodynamics.

Solvent choice criteria are numerous; the solvent must allow an efficient extraction and minimize the required energy for extract and residue desolventization. The solvent mass required per mg of extracted lipids (integrating the extraction yield) was multiplied by the heat of vaporization of each solvent in order to obtain energy $(\mathrm{J})$ per $\mathrm{mg}$ of recovered lipids as second comparison criteria. Solvent ranking is then different (Fig. 6); ethers (MTBE, MeTHF and CPME) required less energy than $\mathrm{CHCl}_{3}$ or EtOAc, and Hep appeared slightly more attractive. If the solvent solubility into to the aqueous phase is included in the comparison criteria (Table 1), MTBE or CPME must be preferred to MeTHF. MTBE and CPME are then the best alternative solvents to chlorinated, followed by MeTHF and EtOAc.

The solvents quantity (between 1 and $5 \mathrm{~g} / \mathrm{mg}$ of extracted lipids) and the related energy for solvent recycling (between 200 and $1000 \mathrm{~J} / \mathrm{mg}$ of extracted lipids) are obviously not compatible with large scale uses and a fortiori for biodiesel production where Higher Heating Value of methyl esters from microalgal oil is $41 \mathrm{~J} / \mathrm{mg}$ [49]. For these purposes, we can estimate that feed-to-solvent ratio and feed concentration have to be increased by a factor a 3 and 10 respectively $(F / S=6$ and a $10 \mathrm{~g} / \mathrm{L}$ biomass concentration), reducing the energy demand for

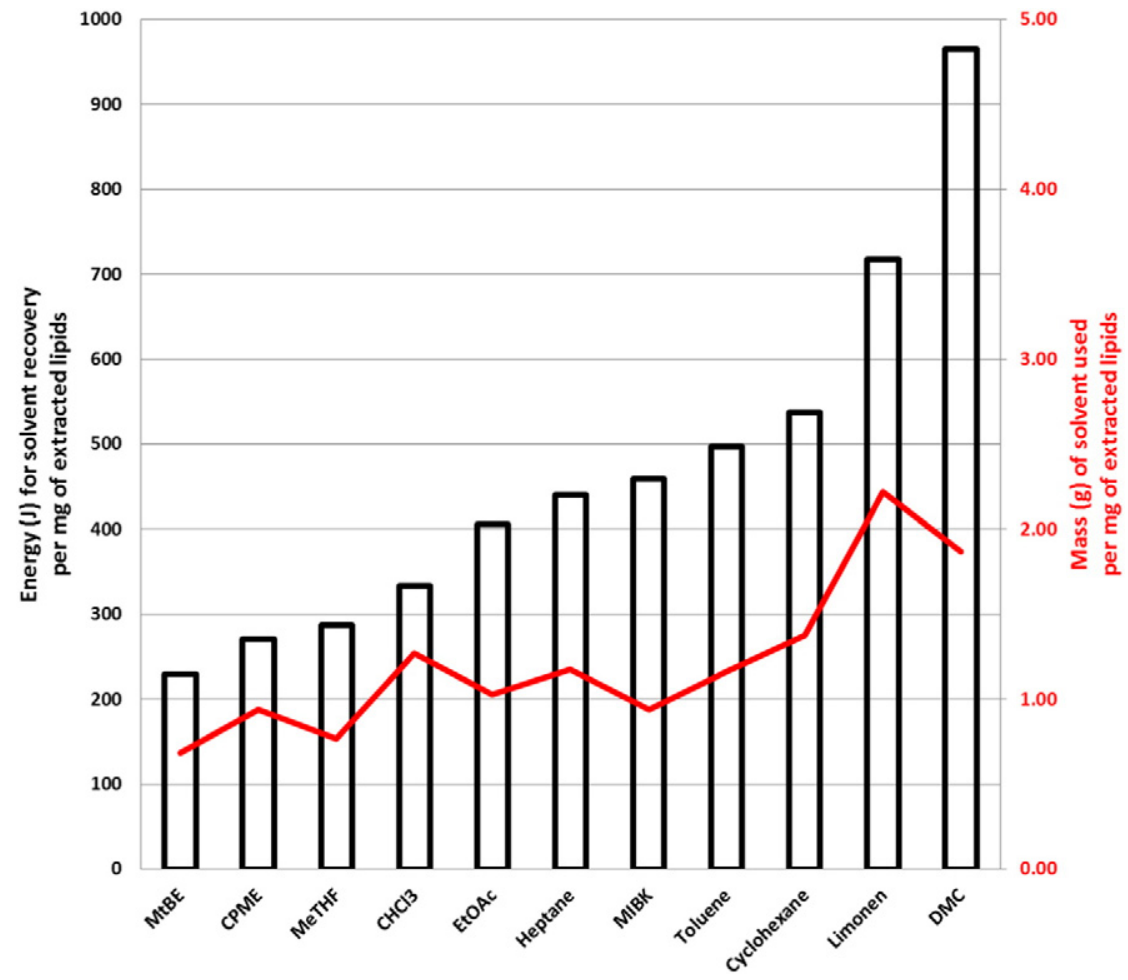

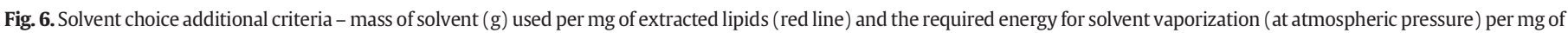
extracted lipids (black histogram). 
solvent recycling to $8-10 \mathrm{~J} / \mathrm{mg}$. In these conditions, wet extraction of lipids after efficient microalgal cell disruption is theoretically feasible and must be validated on pilot-scale process units.

\section{Conclusions}

In the case of biodiesel applications, similar lipid recovery was obtained by wet and dry route extraction, with higher selectivity for TAG. Wet extraction with solvents was controlled by a preliminary cell disruption for intracellular compounds release. Disruption of Nannochloropsis sp. cells needed high energy treatment and this energy increased for depleted and stressed biomass. Solvent screened for short time extraction with constant energy input can be classified into 3 groups corresponding to 3 zones in the Hansen map. MTBE and CPME are interesting alternative solvents to chlorinated, with high lipid extraction efficiency in wet route, minimized energy for solvent recycling and low solubility in water. They are followed by MeTHF and EtOAc. As the feasibility and the efficiency of the lipid wet extraction were demonstrated in the case of disrupted and diluted Nannochloropsis sp., the main issues are the increase of the biomass concentration and the reduction of the solvent volume while maintaining the extraction yield and the liquid-liquid separation. Industrial interest of the operation should be confirmed after process scale-up of the results taking into account the effect of solvent densities, viscosities and interfacial tension on the hydrodynamics inside the extractor.

\section{Acknowledgments}

The authors would like to thank the French National Agency for Research (ANR 12-BIME-0001) for financial support of this study in the framework of the Diesalg program, and Alphabiotech society (Algosource group) for kindly providing the Nannochloropsis sp. strain.

\section{References}

[1] Y. Chisti, Biodiesel from microalgae, Biotechnol. Adv. 25 (3) (2007) 294-306.

[2] M.J. Cooney, G. Young, R. Pate, Bio-oil from photosynthetic microalgae: case study, Bioresour. Technol. 102 (1) (Jan. 2011) 166-177.

[3] I. Rawat, R. Ranjith Kumar, T. Mutanda, F. Bux, Biodiesel from microalgae: a critical evaluation from laboratory to large scale production, Appl. Energy 103 (Mar. 2013) 444-467.

[4] J. Fabregas, A. Maseda, A. Dominguez, A. Otero, The cell composition of Nannochloropsis sp. changes under different irradiances in semicontinuous culture, World J. Microbiol. Biotechnol. 20 (2004) 31-35.

[5] J. Pruvost, G. Van Vooren, B. Le Gouic, A. Couzinet-Mossion, J. Legrand, Systematic investigation of biomass and lipid productivity by microalgae in photobioreactors for biodiesel application, Bioresour. Technol. 102 (1) (Jan. 2011) 150-158.

[6] R. Kandilian, J. Pruvost, J. Legrand, L. Pilon, Influence of light absorption rate by Nannochloropsis oculata on triglyceride production during nitrogen starvation, Bioresour. Technol. 163 (Jul. 2014) 308-319.

[7] K. Sander, G.S. Murthy, Life cycle analysis of algae biodiesel, Int. J. Life Cycle Assess. 15 (2010) 704-714.

[8] L.F. Razon, R.R. Tan, Net energy analysis of the production of biodiesel and biogas from the microalgae: Haematococcus pluvialis and Nannochloropsis, Appl. Energy 88 (10) (Oct. 2011) 3507-3514.

[9] M.K. Lam, K.T. Lee, Microalgae biofuels: a critical review of issues, problems and the way forward, Biotechnol. Adv. 30 (3) (2012) 673-690.

[10] L. Xu, D.W.F. Wim Brilman, J.A.M. Withag, G. Brem, S. Kersten, Assessment of a dry and a wet route for the production of biofuels from microalgae: energy balance analysis, Bioresour. Technol. 102 (8) (Apr. 2011) 5113-5122.

[11] F. Adam, M. Abert-Vian, G. Peltier, F. Chemat, 'Solvent-free' ultrasound-assisted extraction of lipids from fresh microalgae cells: a green, clean and scalable process, Bioresour. Technol. 114 (Jun. 2012) 457-465.

[12] M. Vanthoor-Koopmans, R.H. Wijffels, M.J. Barbosa, M.H.M. Eppink, Biorefinery of microalgae for food and fuel, Bioresour. Technol. 135 (2013) 142-149.

[13] Y. Chisti, Constraints to commercialization of algal fuels, J. Biotechnol. 167 (3) (Sep. 2013) 201-214.

[14] R. Halim, M.K. Danquah, P.A. Webley, Extraction of oil from microalgae for biodiesel production: a review, Biotechnol. Adv. 30 (3) (2012) 709-732.

[15] B.H.J. Yap, G.J. Dumsday, P.J. Scales, G.J.O. Martin, Energy evaluation of algal cell disruption by high pressure homogenisation, Bioresour. Technol. 184 (2015) 280-285

[16] N. Grimi, A. Dubois, L. Marchal, S. Jubeau, N.I. Lebovka, E. Vorobiev, Selective extraction from microalgae Nannochloropsis sp. using different methods of cell disruption, Bioresour. Technol. 153 (Feb. 2014) 254-259.
[17] J. Doucha, K. Livanský, Influence of processing parameters on disintegration of Chlorella cells in various types of homogenizers, Appl. Microbiol. Biotechnol. 81 (3) (Dec. 2008) 431-440.

[18] N. Samarasinghe, S. Fernando, R. Lacey, W.B. Faulkner, Algal cell rupture using high pressure homogenization as a prelude to oil extraction, Renew. Energy 48 (2012) 300-308.

[19] J.R. McMillan, I.A. Watson, M. Ali, W. Jaafar, Evaluation and comparison of algal cell disruption methods: microwave, waterbath, blender, ultrasonic and laser treatment, Appl. Energy 103 (Mar. 2013) 128-134.

[20] V. Montalescot, T. Rinaldi, R. Touchard, S. Jubeau, M. Frappart, P. Jaouen, P. Bourseau, L. Marchal, Optimization of bead milling parameters for the cell disruption of microalgae: process modeling and application to Porphyridium cruentum and Nannochloropsis oculata, Bioresour. Technol. 196 (Nov. 2015) 339-346.

[21] P.R. Postma, T.L. Miron, G. Olivieri, M.J. Barbosa, R.H. Wijffels, M.H.M. Eppink, Mild disintegration of the green microalgae Chlorella vulgaris using bead milling, Bioresour. Technol. 184 (2015) 297-304

[22] E.M. Spiden, B.H.J. Yap, D.R.A. Hill, S.E. Kentish, P.J. Scales, G.J.O. Martin, Quantitative evaluation of the ease of rupture of industrially promising microalgae by high pressure homogenization, Bioresour. Technol. 140 (Jul. 2013) 165-171.

[23] S. Jubeau, L. Marchal, J. Pruvost, P. Jaouen, J. Legrand, J. Fleurence, High pressure disruption: a two-step treatment for selective extraction of intracellular components from the microalga Porphyridium cruentum. J. Appl. Phycol. 25 (4) (2013) 983-989.

[24] E. Ryckebosch, S.P.C. Bermúdez, R. Termote-Verhalle, C. Bruneel, K. Muylaert, R. Parra-Saldivar, I. Foubert, Influence of extraction solvent system on the extractability of lipid components from the biomass of Nannochloropsis gaditana, J. Appl. Phycol. 26 (3) (Jun. 2014) 1501-1510.

[25] L.L. Garcia Alba, Algae Biorefinery, University of Twente, Enschede, The Netherlands, 2013.

[26] M.D. Maćlas-Sánchez, C. Mantell, M. Rodríguez, E. Martínez de la Ossa, L.M. Lubián, O. Montero, Supercritical fluid extraction of carotenoids and chlorophyll a from Nannochloropsis gaditana, J. Food Eng. 66 (2) (Jan. 2005) 245-251.

[27] C.-H. Cheng, T.-B. Du, H.-C. Pi, S.-M. Jang, Y.-H. Lin, H.-T. Lee, Comparative study of lipid extraction from microalgae by organic solvent and supercritical $\mathrm{CO}_{2}$, Bioresour. Technol. 102 (21) (Nov. 2011) 10151-10153.

[28] G. Young, F. Nippgen, S. Titterbrandt, M.J. Cooney, Lipid extraction from biomass using co-solvent mixtures of ionic liquids and polar covalent molecules, Sep. Purif. Technol. 72 (1) (Mar. 2010) 118-121.

[29] Y.H. Kim, Y.K. Choi, J. Park, S. Lee, Y.H. Yang, H.J. Kim, T.J. Park, Y. Hwan Kim, S.H. Lee, Ionic liquid-mediated extraction of lipids from algal biomass, Bioresour. Technol. 109 (2012) 312-315.

[30] M. Virot, V. Tomao, C. Ginies, F. Visinoni, F. Chemat, Green procedure with a green solvent for fats and oils' determination. Microwave-integrated Soxhlet using limonene followed by microwave Clevenger distillation, J. Chromatogr. A 1196-1197 (Jul. 2008) 147-152.

[31] Les agrosolvants en extraction, in: C. Ernenwein, V. Freville, I. Pezron, F. Chemat (Eds.), Eco-extraction du vegetal, Dunod, Paris 2011, pp. 169-205.

[32] C.D. Tanzi, M.A. Vian, C. Ginies, M. Elmaataoui, F. Chemat, Terpenes as green solvents for extraction of oil from microalgae, Molecules 17 (2012) 8196-8205.

[33] C. Dejoye Tanzi, M. Abert Vian, F. Chemat, New procedure for extraction of algal lipids from wet biomass: a green clean and scalable process, Bioresour. Technol. 134 (Apr. 2013) 271-275.

[34] M. Mojaat, A. Foucault, J. Pruvost, J. Legrand, Optimal selection of organic solvents for biocompatible extraction of beta-carotene from Dunaliella salina, J. Biotechnol. 133 (4) (Feb. 2008) 433-441.

[35] J. Canosa, A. Domı, J. Tojo, Viscosities of Dimethyl Carbonate or Diethyl Carbonate with Alkanes at Four Temperatures. New UNIFAC-VISCO Parameters, J. Chem. Eng. Data 48 (1) (2003) 146-151.

[36] B.P. Nobre, F. Villalobos, B.E. Barragán, A.C. Oliveira, A.P. Batista, P.A.S.S. Marques, R.L. Mendes, H. Sovová, A.F. Palavra, L. Gouveia, A biorefinery from Nannochloropsis sp. microalga-extraction of oils and pigments. Production of biohydrogen from the leftover biomass, Bioresour. Technol. 135 (May 2013) 128-136.

[37] R.A. Deeb, K.M. Scow, L. Alvarez-Cohen, Aerobic MTBE biodegradation: an examination of past studies, current challenges and future research directions, Biodegradation 11 (2-3) (2000) 171-186.

[38] G. Van Vooren, F. Le Grand, J. Legrand, S. Cuiné, G. Peltier, J. Pruvost, Investigation of fatty acids accumulation in Nannochloropsis oculata for biodiesel application, Bioresour. Technol. 124 (Nov. 2012) 421-432.

[39] J.A. Berges, D.J. Franklin, P.J. Harrison, Evolution of an artificial seawater medium: improvements in enriched seawater, artificial water over the last two decades, J. Phycol. 37 (6) (Dec. 2001) 1138-1145.

[40] C.M. Hansen, Hansen Solubility Parameters: A User's Handbook, second ed., 2007.

[41] L. Rodolfi, G. Chini Zittelli, N. Bassi, G. Padovani, N. Biondi, G. Bonini, M.R. Tredici, Microalgae for oil: strain selection, induction of lipid synthesis and outdoor mass cultivation in a low-cost photobioreactor, Biotechnol. Bioeng. 102 (1) (Jan. 2009) $100-112$.

[42] P. Bondioli, L. Della Bella, G. Rivolta, G. Chini Zittelli, N. Bassi, L. Rodolfi, D. Casini, M. Prussi, D. Chiaramonti, M.R. Tredici, Oil production by the marine microalgae Nannochloropsis sp. F\&M-M24 and Tetraselmis suecica F\&M-M33, Bioresour. Technol. 114 (2012) 567-572.

[43] A. Vieler, S.B. Brubaker, B. Vick, C. Benning, A lipid droplet protein of Nannochloropsis with functions partially analogous to plant oleosins, Plant Physiol. 158 (4) (Apr. 2012) 1562-1569.

[44] B. Liu, C. Benning, Lipid metabolism in microalgae distinguishes itself, Curr. Opin. Biotechnol. 24 (2) (Apr. 2013) 300-309.

[45] D.J. Murphy, The biogenesis and functions of lipid bodies in animals, plants and microorganisms, Prog. Lipid Res. 40 (5) (Sep. 2001) 325-438. 
[46] D. Simionato, M.A. Block, N. La Rocca, J. Jouhet, E. Maréchal, G. Finazzi, T Morosinotto, The response of Nannochloropsis gaditana to nitrogen starvation includes de novo biosynthesis of triacylglycerols, a decrease of chloroplast galactolipids, and reorganization of the photosynthetic apparatus, Eukaryot. Cell 12 (5) (May 2013) 665-676.

[47] C. Safi, M. Charton, O. Pignolet, F. Silvestre, C. Vaca-Garcia, P.-Y. Pontalier, Influence of microalgae cell wall characteristics on protein extractability and determination of nitrogen-to-protein conversion factors, J. Appl. Phycol. 25 (2) (Aug. 2012) 523-529.
[48] G. Knothe, Dependence of biodiesel fuel properties on the structure of fatty acid alkyl esters, Fuel Process. Technol. 86 (10) (2005) 1059-1070.

[49] X. Miao, Q. Wu, Study on preparation of biodiesel from microalgal oil, Taiyangneng Xuebao/Acta Energiae Solaris Sinica 28 (2007) 219-222. 